\title{
Ecology and Conservation Status of Threatened Orchid Dactylorhiza hatagirea (D. Don) Soo in Manaslu Conservation Area, Central Nepal
}

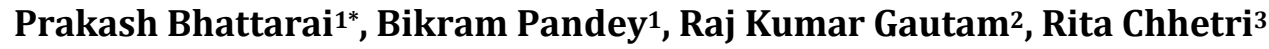 \\ ${ }^{1}$ Central Department of Botany, Tribhuvan University, Kathmandu, Nepal \\ ${ }^{2}$ Makawanpur Multiple Campus, Hetauda, Nepal \\ ${ }^{3}$ National Herbarium and Plant Laboratories, Lalitpur, Nepal \\ Email: ${ }^{*}$ light.bhattarai@gmail.com
}

Received 30 September 2014; revised 24 October 2014; accepted 9 November 2014

Copyright (C) 2014 by authors and Scientific Research Publishing Inc.

This work is licensed under the Creative Commons Attribution International License (CC BY).

http://creativecommons.org/licenses/by/4.0/

(c) (i) Open Access

\begin{abstract}
Dactylorhiza hatagirea (D. Don) Soo, commonly known as "Panchaunle", is an important medicinal plant species distributed throughout the Himalaya region. The present work was conducted in order to assess its availability in natural habitats because of its medicinal properties, cultural significance and declining population density. The work focused primarily on its ecological features and conservation status. The density of $D$. hatagirea was found to be 2.18 individuals $\cdot \mathrm{m}^{-2}$ with frequency and abundance being $81.81 \%$ and 2.67 individuals $\cdot \mathrm{m}^{-2}$, respectively. We considered grazing, trampling, number of cattle and distance to settlement as anthropogenic factors. While grazing and trampling were shown to have a significant, negative impact on population density, we observed no significant change in the number of the species with respect to number of cattle and distance to settlement. We conclude that the species is threatened and that anthropogenic factors have a significant effect on its habitation in the study area.
\end{abstract}

\section{Keywords}

Anthropogenic, Grazing, Medicinal Plants, Population Density, Threatened

\section{Introduction}

Orchidaceae, the orchid family, is a morphologically diverse and geographically widespread family of monocots

${ }^{*}$ Corresponding author.

How to cite this paper: Bhattarai, P., Pandey, B., Gautam, R.K. and Chhetri, R. (2014) Ecology and Conservation Status of Threatened Orchid Dactylorhiza hatagirea (D. Don) Soo in Manaslu Conservation Area, Central Nepal. American Journal of Plant Sciences, 5, 3483-3491. http://dx.doi.org/10.4236/ajps.2014.523364 
in the order Orchidales. They are found in a variety of ecological conditions and generally occur in four forms based on their habitat (i.e. terrestrial, epiphytic, lithophytic and saprophytic). Among these, the terrestrial species accounts for approximately one-third of the family [1] [2]; this species tends to live in small isolated populations placing them at risk of extinction [2].

Orchidaceaeis believed to be the second largest family of flowering plants after Asteraceae, with between 21,950 and 26,049 currently accepted species, grouped into 880 genera. The largest genera are Bulbophyllum (2000 species), Epidendrum (1500 species), Dendrobium (1400 species) and Pleurothallis (1000 species) (World Checklist of Selected Families, 2013). Nepal harbors 437 species of orchid belonging to 104 genera [3].

Dactylorhiza Necker ex Nevski (Orchidaceae) is a genus of about 75 species, distributed throughout the world with 58 species in Europe and North Africa [4]. The greatest species richness is found in north-western Europe, though only nine species of Dactylorhiza are endemic. The distribution of Dactylorhiza covers most of Europe, temperate Asia, North Africa, Japan, the Aleutian Islands and northern parts of North America. Dactylorhiza is a very challenging genus as it consistently presents taxonomic difficulties [5] [6]. Only one species of Dactylorhiza hatagirea is extended throughout Nepal from an altitudinal range of $2800 \mathrm{~m}$ to $3900 \mathrm{~m}$ [7] in terrestrial habitat [8]. Apart from the Nepal Himalaya, the species is distributed in India, Bhutan, China, Mongolia, Pakistan and Russia [7]. It is found in grassland slopes or among shrubs, in the upper belt of the temperate to alpine climate zone.

The use of orchids as medicine has a very long history. Chinese were the first to use them as an herbal medicine [9]. The presence of phytochemicals such as alkaloids, flavonoids, and glycosides has made orchids valuable as medicine. Although the Convention on International Trade in Endangered Species of wild fauna and flora (CITES) Nepal has enlisted orchid in its Appendix II where the exploitation, collection and trade are banned, the use of orchids as a medicine for local purposes, as well as its collection and trade through illegal channels [7], has led to pressure on its natural habitat [10] [11].

The threat to the species generally arises due to its panoply of uses. Dactylorhiza hatagirea is one of the highest valued medicinal orchids extensively used in Ayurveda. The tubers of this species yield high quality "Selep" which is used extensively for its aphrodisiac properties and sexual stimulant in traditional medicine in different parts of Himalaya [12]-[15]. Apart from this, the tuber is used as farinaceous food and nerve tonic [12] [13]. The paste is also considered nutritive and used in treating weakness in children and women [15]. Root powder is spread on wounds to control bleeding [11] [13]. In addition, the plant possesses antibacterial properties and the whole plant is used in curing various ailments caused by bacteria; the aerial part is effective to inhibit Escherichia coli while the rhizome is effective in treating a disease caused by Shigella flexinerai [16].

The abundance and distribution ranges of orchid species have undergone dramatic declines in recent decades [17]. Habitat loss and fragmentation are considered important factors in the decline of Dactylorhiza [1] [17] [18]: the smaller population sizes and greater degree of population isolation are strongly associated with the general decline and extinction risk of the population as a whole [19] [20].

Thus, the species is threatened and various anthropogenic factors presently confine the species to small, isolated populations. In the light of these circumstances, this study aims to 1) sample the present ecological data of the species and regress them with different anthropogenic factors; and 2) identify the threats to the species in the Manaslu Conservation Area.

\section{Materials and Methods}

\subsection{Study Area}

The Manaslu Conservation Area (MCA) is a remote natural conservation area in Nepal. The MCA lies in the Gorkha District of Central Nepal and stretches between $28^{\circ} 21^{\prime} \mathrm{N}-28^{\circ} 45^{\prime} \mathrm{N}$ latitude and $84^{\circ} 30^{\prime} \mathrm{E}-85^{\circ} 21^{\prime} \mathrm{E}$ longitude (Figure 1). The altitude ranges from $1400 \mathrm{~m}$ to $8163 \mathrm{~m}$ and comprises a total area of $1663 \mathrm{sq} . \mathrm{km}$. The total area of the MCA is $1663 \mathrm{sq}$. km ranging from $1400 \mathrm{~m}$ (Jagat) to $8163 \mathrm{~m}$ (Mt. Manaslu). The conservation area comprises of seven village development committee (VDCs), Sirdibas, Bihi, Prok, Lho, Samagaun, Chumchet and Chhekampar whereas the present study focuses on the altitudinal range between $2800 \mathrm{~m}$ to $4200 \mathrm{~m}$ in Samagaun Village, where anabundance of Dactylorhiza hatagirea was recorded.

Four different climate zones are noted in this region: the subtropical zone (1000 $\mathrm{m}$ to $2000 \mathrm{~m}$ ), the temperate zone ( $2000 \mathrm{~m}$ to $3000 \mathrm{~m}$ ), the subalpine zone ( $3000 \mathrm{~m}$ to $4000 \mathrm{~m}$ ) and the alpine zone ( $4000 \mathrm{~m}$ to $5000 \mathrm{~m}$ and above) whereas our study was mostly confined to subalpine zone. The altitudinal range and abundance of diffe- 


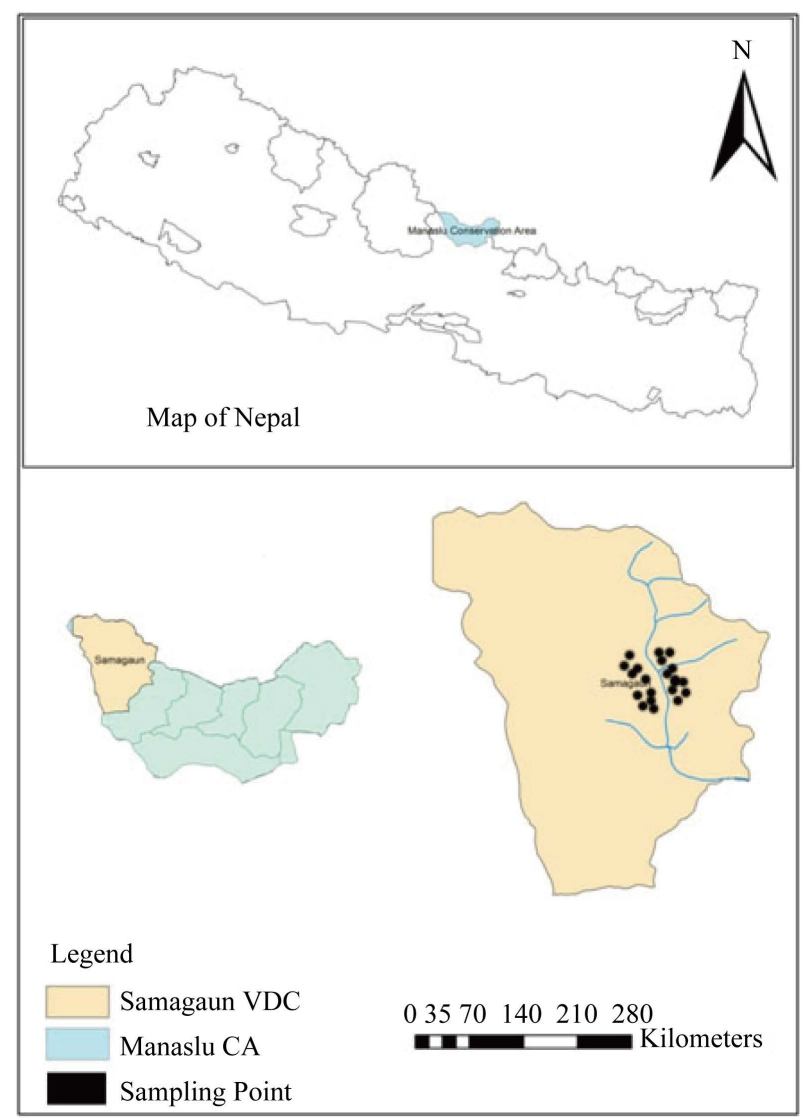

Figure 1. Map of study area (Source: Arc GIS 9.0).

rent types of habitats and microclimatic conditions in the MCA present a unique and ideal site for the availability of varied types of flora and vegetation within short distances. The MCA is chiefly populated by east Himalayan species like Larix himalaica, Schima wallichii and Castanopsis indica whereas Picea smithiana is a western Himalayan species. The availability of the species of Rhododendron (R. arboreum, R. anthopogon, R. barbatum and $R$. campanulatum) is mainly in high altitude of MCA.

\subsection{Data Collection and Analysis}

A preliminary study was carried out in October, 2012. During this period, the study site and sampling areas were selected, and general information concerning the flora (viz., D. hatagirea) was documented. The principal visit was conducted during the months of June and July, 2013. All necessary data were collected during that period.

A semi-systematic sampling method was used for data collection to cover all the possible habitats and associated vegetation types of $D$. hatagirea. Sampling was performed on both aspects and on both sides of Budi Gandaki River. The sampling methods were designed to include all the habitat types and vegetation types within $3450-4050 \mathrm{~m}$. A total of 77 plots of $1 \times 1 \mathrm{~m}^{2}$ quadrate each at $50 \mathrm{~m}$ belt were sampled. The distance between two plots was approximately $10 \mathrm{~m}$ (walking distance). Every species (excluding grasses) in the sample plot was recorded separately and the process was repeated in successive plots. Longitude, latitude and elevation of each sample plot were recorded by Global Positioning System (GPS, eTrex Garmin) and elevation was cross-checked by a standardized altimeter. A GPS was use to note the location of shed of livestock as well. Slope and aspect of each plot were recorded by a clinometer compass.

Grazing, trampling, number of livestock and distance from the nearest settlement were considered as an anthropogenic disturbances. The anthropogenic disturbances were recorded in a scale of 0 to 3 . For instance, when codifying grazing levels, 0 was given to non-grazing, whereas 1,2 and 3 was given to low, moderate and high grazing levels, respectively. The comparison was done based on evidence of eaten leaves of $D$. hatagirea, 
presence of dung and uprooted parts of other plants, the distance from the nearest settlement and goth (cattle shed). An analogous method was used for trampling measures.

We calculated frequency and density of the D. hategeria using [21]. We used Generalized Linear Model $(G L M)$ [22] to regress the species number to the anthropogenic factors on the normally dispersed data. Anthropogenic factors were tested up to the second order polynomial to evaluate the significance of additional deviance and monotonic patterns.

\subsection{Threats Assessment}

A pre-designed questionnaire was used to determine the conservation status of the $D$. hatagirea in studied area, targeting the respondents of age group between 25 - 60 years $(n=75)$. Analyses were done using Microsoft Excel. Apart from this, focus group discussion was done in Samagaun Village at the premises of Mr. Karma Tsewang Lama with the help of members from the Samagaun Youth Club. The ideas generated in this group discussion were further used in the results portion.

\section{Results}

\subsection{Density, Frequency and Abundance}

Population of D. hatagirea was found to distribute between 3450 - $4050 \mathrm{~m}$ of elevation. In total, four micro habitats of $D$. hatagirea were identified in the study site. The species gradually grows in association with other species with varying direction. However, south-east was the most preferred aspect. The recorded slopes of natural habitats were between $10^{\circ}-54^{\circ}$. The random distribution of species in small fragmented patches suggests its patchy or scattered distribution. Total 55 plant species including $D$. hatagirea were present in study area (Table 1).

The population density of $D$. hatagirea in its natural habitats was 2.18 individuals $\cdot \mathrm{m}^{-2}$. The frequency, relative density, relative frequency and abundance were $81.81 \%, 2.02 \%, 7.48 \%$ and 2.667 individual $/ \mathrm{m}^{2}$ (26666.67 individual/hectare), respectively. Density of $D$. hatagirea varied according to micro habitat. An open land (4.06 individuals $\cdot \mathrm{m}^{-2}$ ) with $94 \%$ bears the highest density whereas meadows $\left(0.67\right.$ individuals $\left.\cdot \mathrm{m}^{-2}\right)$ represent the least. In addition, the highest abundance of $D$. hatagirea (4.312 individuals $\cdot \mathrm{m}^{-2}$ ) was also recorded on open land (Table 2).

\subsection{Density of $D$. hatagirea and Anthropogenic Influence}

We included grazing, trampling, distance from the nearest human settlement and population of livestock in 500 $m$ periphery as an anthropogenic variables. While grazing and trampling had a significant effect on population density ( $p<0.05$ ) of the species, we failed to observe any significant changes in species densities as a result of distance to the settlement or number of cattle species present in the periphery. The density of the species decreases with increasing grazing pressure and trampling (Figure 2).

\subsection{Threat Assessment}

We found the entirety of our respondents had at least a passing knowledge of Dactylorhiza hatagirea. They were well informed about the availability of targeted species in the natural habitat. They were, however, generally ignorant of the means of its propagation.

Around $81.25 \%$ of respondents use the plant species for various purpose i.e. medicinal, nerve tonic, ornamental and vegetable but only $7.5 \%$ respondent mention its religious uses. The whole of respondents use the plant rhizome in cuts and wounds. The paste from the tuber is applied in the wound caused by cuts. The plant is very useful in treating stomachache, cold and some time given to the pregnant women. The dried and powdered tuber is also on occasion mixed with yak milk and honey along with Yarshagunbu (Ophiocordyceps sinensis) which acts as a tonic and is sometimes given to children. The whole dry tuber is put inside the bottle of the alcohol which adds the flavour to the alcohol. The powder is also very effective in seminal debility, diarrhoea and chronic pain. The flowers are attractive in colour and often used for decorative purposes.

Although the plant is prohibited for harvesting, the majority of the respondents (84.37\%) were unaware of this prohibition. The harvesting is done by the use of traditional tools. $37.50 \%$ of respondents do possess livestock 
Table 1. List of plant species with their frequency and density found on the study plots.

\begin{tabular}{|c|c|c|c|c|}
\hline S. No. & Plant species & Family & Frequency & $\begin{array}{c}\text { Density } \\
\left(\text { individual } \cdot \mathrm{m}^{-2} \text { ) }\right.\end{array}$ \\
\hline 1 & Allium wallichii Kunth & Amaryllidaceae & 66.12 & 1.28 \\
\hline 2 & Anaphalis triplinervis (Sims) C. B. Clarke & Asteraceae & 77.12 & 2.12 \\
\hline 3 & Androsace strigillosa Franch & Primulaceae & 68.57 & 1.76 \\
\hline 4 & Anemone demissa Hook. f \& Thomson & Ranunculaceae & 83.43 & 2.92 \\
\hline 5 & Aquilegia moorcroftiana Wall. ex Royle & Ranunculaceae & 55.90 & 1.08 \\
\hline 6 & Arisaema jacquemontii Blume & Aeraceae & 43.22 & 0.84 \\
\hline 7 & Artemisia gmelinii Web. ex Stechm & Asteraceae & 55.64 & 1.42 \\
\hline 8 & Asparagus filicinus Buch.-Ham. ex D. Don & Asparagaceae & 58.92 & 1.02 \\
\hline 9 & Aster albescens (DC.) Hand.-Mazz. & Asteraceae & 52.24 & 0.42 \\
\hline 10 & Astragalus floridus Benth. ex Bunge & Fabaceae & 61.79 & 2.32 \\
\hline 11 & Astragalus melanostachys Benth. ex Bunge & Fabaceae & 51.34 & 1.12 \\
\hline 12 & Berberis erythroclada Ahrendt. & Berberidaceae & 84.98 & 3.82 \\
\hline 13 & Bistorta macrophylla (D. Don) Sojak & Polygonaceae & 90.24 & 4.56 \\
\hline 14 & Caragana gerardiana Royle & Fabaceae & 76.14 & 2.84 \\
\hline 15 & Caragana sukiensis C. K. Schneid. & Fabaceae & 64.87 & 2.59 \\
\hline 16 & Cassiope fastigiata (Wall.) D. Don & Ericaceae & 68.56 & 2.85 \\
\hline 17 & Chesneya nubigena (D. Don) Ali & Fabaceae & 85.62 & 2.22 \\
\hline 18 & Clametis barbellata Edgew. & Ranunculaceae & 42.04 & 0.68 \\
\hline 19 & Corydalis chaerophylla DC. & Papaveraceae & 62.36 & 1.47 \\
\hline 20 & Cotoneaster microphyllus Wall. ex Lindl. & Rosaceae & 88.18 & 2.98 \\
\hline 21 & Cypripedium himalaicum Rolfe apud Hemsl. & Orchidaceae & 56.32 & 1.36 \\
\hline 22 & Dactylorhiza hatageria (D. Don) Soo & Orchidaceae & 81.81 & 2.18 \\
\hline 23 & Ephedra gerardiana Wall. ex Stapf & Ephedraceae & 82.14 & 2.02 \\
\hline 24 & Erysimum melicentae Dunn & Brassicaceae & 42.34 & 0.32 \\
\hline 25 & Euphorbia wallichii Hook. F. & Euphorbiaceae & 76.42 & 2.28 \\
\hline 26 & Fagopyrum dibortys (D. Don) H. Hara & Polygonaceae & 68.68 & 2.12 \\
\hline 27 & Fritillaria cirrhosa D. Don & Liliaceae & 66.95 & 1.93 \\
\hline 28 & Fragaria nubicola Lindl. ex Lacaita & Rosaceae & 82.37 & 2.84 \\
\hline 29 & Gentiana ornata (D. Don) Griseb. & Gentianaceae & 78.08 & 3.42 \\
\hline 30 & Geranium pretense $\mathrm{L}$. & Geraniaceae & 79.35 & 2.78 \\
\hline 31 & Hedysarum kumaonense Benth. ex Baker & Fabaceae & 66.59 & 1.75 \\
\hline 32 & Hedysarum sikkimense Benth. ex Baker & Fabaceae & 62.14 & 1.66 \\
\hline 33 & Iris stantonii H. Hara & Iridaceae & 54.38 & 1.23 \\
\hline 34 & Juniperus indica Bertol. & Cupressaceae & 63.32 & 1.12 \\
\hline 35 & Megacodon stylophorus (C. B. Clarke) H. Sm. & Gentianaceae & 56.63 & 0.97 \\
\hline 36 & Morina nepalensis D. Don & Dipsacaceae & 87.89 & 2.98 \\
\hline 37 & Morina polyphylla Wall. ex DC. & Dipsacaceae & 92.91 & 3.68 \\
\hline 38 & Nannoglottis hookeri (C. B. Clarke ex Hook. f.) Kitam. & Asteraceae & 61.29 & 1.80 \\
\hline
\end{tabular}




\section{Continued}

\begin{tabular}{lllll}
\hline 39 & Oxytropis microphylla (Pall.) DC. & Fabaceae & 60.90 & 1.69 \\
40 & Pedicularis poluninii Tsoong & Scrophulariaceae & 83.81 & 3.01 \\
41 & Ponerorchis chusua (D. Don) Soo & Orchidaceae & 80.04 & 2.86 \\
42 & Potentilla cuneata Wall. ex Lhem. & Rosaceae & 78.81 & 1.96 \\
43 & Potentilla fructicosa L. & Rosaceae & 64.67 & 1.46 \\
44 & Primula rotundifolia Wall. & Primulaceae & 61.09 & 1.31 \\
45 & Rhododendron anthopogon D. Don & Ericaceae & 89.75 & 2.84 \\
46 & Rhododendron lepidotum Wall. ex G. Don & Ericaceae & 81.63 & 2.60 \\
47 & Rosa sericea Lindl. & Rosaceae & 62.12 & 1.65 \\
48 & Rumex nepalensis Spreng & Polygonaceae & 64.56 & 1.66 \\
49 & Salix calyculata Hook. f. ex Andersson & Salicaceae & 77.39 & 1.78 \\
50 & Salix sikkimensis Andersson & Salicaceae & 54.63 & 0.86 \\
51 & Spiranthes sinensis (Pers.) Ames & Orchidaceae & 66.42 & 1.44 \\
52 & Swertia angustifolia Buch.-Ham. ex D. Don & Gentianaceae & 69.84 & 2.08 \\
53 & Thermopsis barbata Royle & Fabaceae & 74.46 & 88.98 \\
54 & Viola biflora L. & Violaceae & & 3.90 \\
\hline
\end{tabular}

Table 2. Availability and status of Dactylorhiza hatagirea in study area.

\begin{tabular}{cccc}
\hline Micro habitat & Frequency (\%) & $\begin{array}{c}\text { Density } \\
\text { (individuals } \mathbf{m}^{\mathbf{- 2}} \text { ) }\end{array}$ & $\begin{array}{c}\text { Abundance } \\
\left(\text { individuals } \cdot \mathbf{m}^{-\mathbf{2}} \text { ) }\right.\end{array}$ \\
\hline Scrubland & 85.42 & 1.79 & 2.1 \\
Rocky surface & 55.56 & 1.22 & 2.2 \\
Meadows & 33.33 & 0.67 & 2.0 \\
Open land & $\mathbf{9 4 . 1 2}$ & $\mathbf{4 . 0 6}$ & $\mathbf{4 . 3 1}$ \\
\hline
\end{tabular}
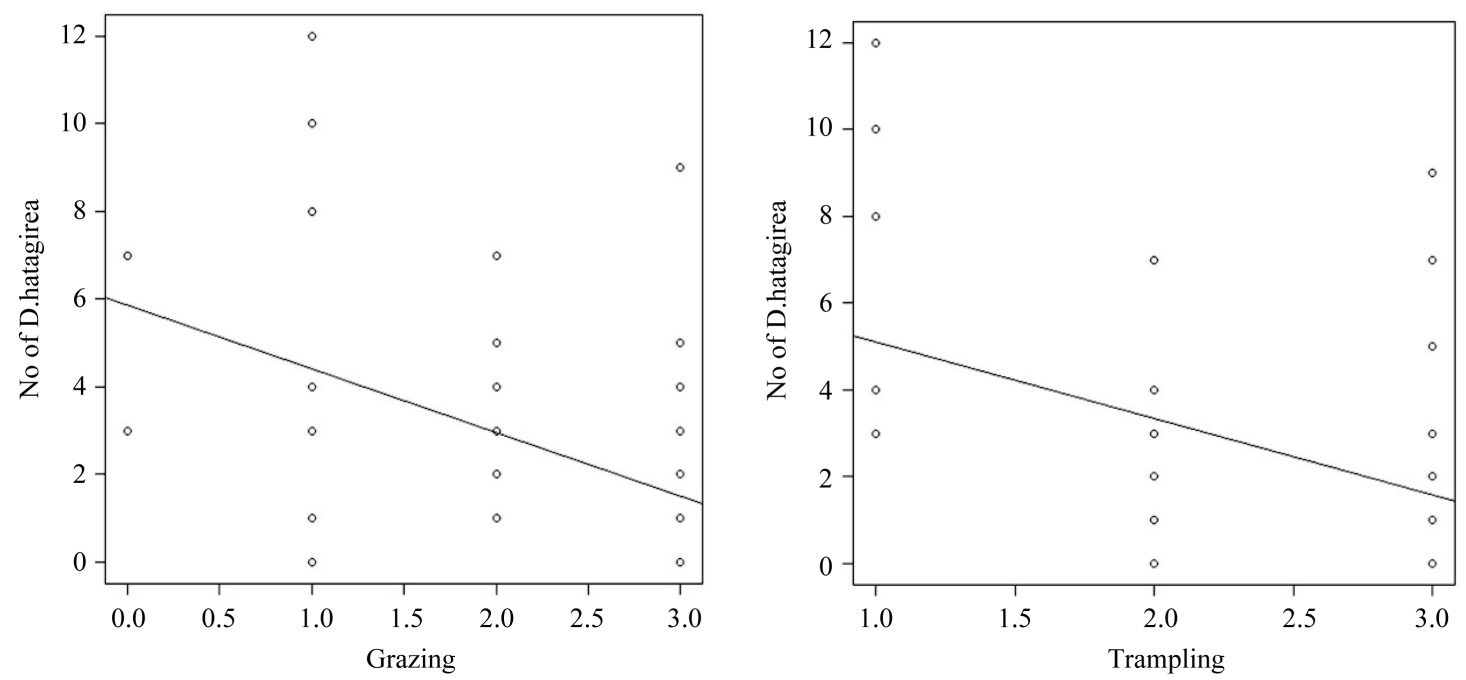

Figure 2. Relationship between density of $D$. hatagirea with grazing and trampling.

and practice transhumance; hence there is a seasonal movement of livestock in the area.

We found that the shed of livestock were located far from the human settlement but nearby the study plot. The livestock were left open in the area for grazing.

Only $15.63 \%$ of respondents were aware of the policies and the regulations related to the collection of the 
plant parts. As mentioned above, the bulk of respondents are unaware of the ban on its collection. Although, no local people have any involvement for its illegal collection and trade, we cannot underestimate the possibilities of its trade through illegal channels. All respondents were informed about the general decline of the species from natural habitat loss through collection pressure and unscientific harvesting.

\section{Discussion}

Dactylorhiza hatagirea showed high density in the open slope in alpine region whereas its availability in the open slope of sub-alpine region was minimum and from conservation point of view, such species are more important. Species with specific habitat requirements have greater possibility of extinction than the species with broad habitat range [23]. Majority of plant taxa of endangered and rare categories grow in Nepal Himalaya are under the pressure of exploitation and destruction of their natural habitats [24] [25]. Similarly, orchid species are facing the greatest threat due to human encroachment, habitat loss, forest destruction and degradation [10] [11].

The density of $D$. hatagirea varied with different management practice. We found the population density to be 2.182 individuals $\cdot \mathrm{m}^{-2}$ whereas [18] [26] [27] and [28] as $1.0-4.2$ individual $\cdot \mathrm{m}^{-2}, 1.13-2.19$ individuals $\cdot \mathrm{m}^{-2}$, $0.37-18.0$ individuals $\cdot \mathrm{m}^{-2}$ and 0.4 individual $\cdot \mathrm{m}^{-2}$ respectively. The variation in the above studies mentioned different degree of grazing and trampling as a major cause to decrease the density of $D$. hatagirea. Similarly in this study as well, different degree of grazing and trampling resulted in low density of targeted species.

Moreover, trampling by livestock was also noted as a major factor for depletion of its population in natural habitat. In relation to this observation, [9] [15] [24] and [29] highlighted the over-collection and grazing pressure as the means of disturbances mostly responsible for low density and continuous decline of plant population. Although based on the report published by [30], local user are responsible for managing locally available resource such as forest, grassland, alternate source of energy and local tourism for enhancing their livelihood opportunity but due to mismanage grazing, the population of $D$. hatagirea is been decline. Moreover, [31] also reported the decline in species richness of vascular plants with respect to grazing.

Similarly, [18] also observed that frequent extraction and increase in grazing pressure were mainly responsible for low population status of $D$. hatagirea in Central Himalaya. Transhumance pastoralism and increasing livestock number in the Himalaya have negative impact on abundance of the species due to mismanage grazing [32]. Similar threat has been experienced in the study area where we found the livestock were grazing in $D$. Hatagirea potential area. Moreover, from the questionnaire survey it was found that the nomads in the study area practiced transhumance in flowering and fruiting season. Overgrazing and trampling by the livestock result to destroy the aerial parts. Mismanage grazing and periodic movement of livestock in the study area has resulted in the destruction of habitat which further results in low population density of $D$. hatagirea.

The distribution in fragmented habitats and the wide variation in frequency of occurrence of $D$. hatagirea suggest a high potentiality of the species to grow over large areas, but due to increase anthropogenic activities it seems unable to form large continuous distribution boundaries [2]. Lacking endosperm, the seeds of $D$. hatagirea can germinate with only symbiotic fungi in natural conditions. Due to over disturbances and habitat fragmentation it increases mating opportunity between closely related individuals and finally results in loss of genetic diversity [2] [33].

\section{Conclusion}

The present study reveals that the density of $D$. Hatagirea in protected areas is under continuous threats. The relative density, relative frequency and abundance $\left(2.02 \%, 7.48 \%\right.$ and 2.667 individual $\cdot \mathrm{m}^{-2}$, respectively) indicates that the associate species play a significant role in its distribution. The major associated species were Anemone demissa, Bistorta macrophylla, Chesneya nubigena, Morina nepalensis, Morina polyphylla etc. Dactylorhiza hatagirea is listed in Appendix II of CITES, and its collection and trade are prohibited, however, there is a decrease in the availability of $D$. hatagirea, due to increase in pressure from grazing and trampling. Lack of awareness, harvesting for personal use, lack of conservation plan in the study area may collectively account to decline $D$. hatagirea.

\section{Acknowledgements}

We would like to acknowledge Rufford Small Grant for Nature Conservation for financial support and Idea wild 
for equipments support to conduct this study. Furthermore we would like to thank Manaslu Conservation Area Project, National Trust for Nature Conservation for providing research permission in the study area. We would also like to thank local communities who shared their valuable knowledge and information during the field work. Sincere thanks goes to staff and students of Buddha Secondary School, Phillim (Sirdibas) and the members of the Samagaun Youth Club. Last but not least, we would like to thank Mr. Daniel Tucker for English edition and proof read of this article.

\section{References}

[1] Swarts, N.D. and Dixon, K.W. (2009) Terrestrial Orchid Conservation in the Age of Extinction. Annals of Botany, 104, 543-556. http://dx.doi.org/10.1093/aob/mcp025

[2] Warghat, A.R., Bajpai, P.K., Srivastava, R.B., Chaurasia, O.P. and Sood, H. (2013) Population Genetic Structure and Conservation of Small Fragmented Location of Dactylorhiza hatagirea in Ladakh Region of India. Scientia Horticulturae, 164, 448-454. http://dx.doi.org/10.1016/j.scienta.2013.09.044

[3] Rokaya, M.B., Raskoti, B.B., Timsina, B. and Munzbergova, Z. (2013) An Annotated Checklist of the Orchids of Nepal. Nordic Journal of Botany, 31, 511-550. http://dx.doi.org/10.1111/j.1756-1051.2013.01230.x

[4] Averyanov, L.M. (1990) A Review of the Genus Dactylorhiza. In: Ardit, J., Ed., Orchis Biology: Reviews and Perspectives, $V$, Timber Press, Oregon, 159-206.

[5] Pedersen, H.E. (1998) Species Concept and Guidelines for Infraspeciefic Taxonomic Ranking in Dactylorhiza (Orchidaceae). Norwegian Journal of Botany, 18, 289-310. http://dx.doi.org/10.1111/j.1756-1051.1998.tb01881.x

[6] Hedren, M. (2001) Conservation Priorities in Dactylorhiza, a Taxonomically Complex Genus. Lindleyana, 16, 17-25.

[7] Raskoti, B.B. (2009) The Orchid of Nepal. Bhakta Bahadur Raskoti and Rita Ale, Kathmandu.

[8] Flora of China Editorial Committee (2009) Flora of China (Orchidaceae). In: Wu, Y., Raven, P.H. and Hong, D.Y., Eds., Flora of China, Science Press \& Missouri Botanical Garden Press, Beijing, 1-570.

[9] Bulpitt, C.J. (2005) The Uses and Misuses of Orchids in Medicine. QJM: An International Journal of Medicine, 98, 625-631. http://dx.doi.org/10.1093/qjmed/hci094

[10] Acharya, K.P. and Rokaya, M.B. (2010) Medicinal Orchids of Nepal: Are They Well Protected? Our Nature, 8, 82-91.

[11] Pant, B. and Raskoti, B.B. (2013) Medicinal Orchid of Nepal. Himalayan Map House Pvt. Ltd., Kathmandu.

[12] Watanabe, T., Rajbhandari, K.R., Malla, K.J. and Yahara, S. (2005) A Handbook of Medicinal Plants of Nepal. Kobfai Publishing Project, Foundation for Democracy and Development Studies, Bangkok.

[13] Baral, S.R. and Kurmi, P.P. (2006) A Compendium of Medicinal Plants in Nepal. Mass Printing Press, Kathmandu.

[14] Thakur, M. and Dixit, V.K. (2007) Aphrodisiac Activity of Dactylorhiza hatagirea (D. Don) Soo in Male Albino Rats. Evidence-Based Complementary and Alternative Medicine, 4, 29-31.

[15] Giri, D. and Tamta, S. (2010) A General Account on Traditional Medicinal Uses of Dactylorhiza hatagirea (D. Don) Soo. New York Science Journal, 3, 78-79.

[16] Ranpal, S. (2009) An Assessment of Status and Antibacterial Properties of Dactylor hizahatagirea in Annapurna Conservation Area, a Case Study of Paplekharka, Lete VDC, Mustang. Master's Dissertation, Institute of Forestry, Tribhuvan University, Kathmandu.

[17] Kulla, T. and Hutchings, M.J. (2006) A Comparative Analysis of Decline in the Distribution Ranges of Orchid Species in Estonia and the United Kingdom. Biological Conservation, 129, 31-39. http://dx.doi.org/10.1016/j.biocon.2005.09.046

[18] Sharma, P.K., Sharita, S. and Prell, J. (2005) Dactylor hizahatagirea (D. Don) Soo-A West Himalayan Orchid in Peril. Current Science, 89, 610-612.

[19] Fischer, M. and Matthies, D. (1998) Effects of Population Size on Performance in the Rare Plant Gentianella germanica. Journal of Ecology, 86, 195-204. http://dx.doi.org/10.1046/j.1365-2745.1998.00246.x

[20] Matthies, D., Brauer, I., Maibom, W. and Tscharntke, T. (2004) Population Size and the Risk of Local Extinction: Empirical Evidence from Rare Plants. Oikos, 105, 481-488. http://dx.doi.org/10.1111/j.0030-1299.2004.12800.x

[21] Zobel, D.B., Behan, M.J., Jha, P.K. and Yadav, U.R.K. (1987) A Practical Manual for Ecology. Ratna Book Distributors, Kathmandu.

[22] MacCullagh, P. and Nelder, J.A. (1989) Generalized Linear Models. CRC Press, Boca Raton.

[23] Lomolino, M.V. (2001) Elevation Gradient of Species-Density: Historical and Prospective Views. Global Ecology and Biogeography, 10, 3-13. http://dx.doi.org/10.1046/j.1466-822x.2001.00229.x

[24] Manandhar, N.P. (1990) Some of the Medicinal Plants of Nepal. Ancient Science of Life, 9, 231-233. 
[25] Shrestha, T.B. and Joshi, R.M. (1996) Rare, Endemic and Endangered Plants of Nepal. WWF Nepal Program, Kathmandu.

[26] Uniyal, S.K., Awasthi, A. and Rawat, G.S. (2002) Current Status and Distribution of Commercially Exploited Medicinal and Aromatic Plants in Upper Gori Valley, Kumaon Himalaya, Uttaranchal. Current Science, 82, 1246-1252.

[27] Kala, C.P. (2005) Indeginous Uses, Population Density and Conservation Areas of the Indaian Himalaya. Conservation Biology, 19, 368-378. http://dx.doi.org/10.1111/j.1523-1739.2005.00602.x

[28] Jalal, J.S. and Rawat, G.S. (2009) Habitat Studies for Conservation of Medicinal Orchids of Uttarakhand, Western Himalaya. African Journal of Plant Science, 3, 200-204.

[29] Kala, C.P. (2000) Status and Conservation of Rare and Endangered Medicinal Plants in Indian Trans-Himalaya. Biological Conservation, 93, 371-379. http://dx.doi.org/10.1016/S0006-3207(99)00128-7

[30] GoN (2008) National Capacity Self-Assessment for Global Environmental Management. Nepal Thematic Assessment Report: Biodiversity. Ministry of Environment, Science and Technology, Kathmandu.

[31] Bhattarai, P., Bhatta, K.P., Chhetri, R. and Chaudhary, R.P. (2014) Vascular Plant Species Richness along Elevation Gradients of the Karnali River Valley, Nepal Himalaya. International Journal of Plant, Animal and Environmental Sciences, 4, 114-126.

[32] Olea, P.P. and Mateo-Tomas, P. (2009) The Role of Traditional Farming Practice in Ecosystem Conservation: The Case of Transhumance and Vulture. Biological Conservation, 142, 1844-1853. http://dx.doi.org/10.1016/j.biocon.2009.03.024

[33] Pillon, Y., Ray, M.F., Shipunov, A.B. and Chase, M.W. (2006) Species Diversity versus Phylogenetic Diversity: A Practical Study in the Taxonomically Difficult Genus Dactylorhiza (Orchidaceae). Biological Conservation, 129, 4-13. http://dx.doi.org/10.1016/j.biocon.2005.06.036 
Scientific Research Publishing (SCIRP) is one of the largest Open Access journal publishers. It is currently publishing more than 200 open access, online, peer-reviewed journals covering a wide range of academic disciplines. SCIRP serves the worldwide academic communities and contributes to the progress and application of science with its publication.

Other selected journals from SCIRP are listed as below. Submit your manuscript to us via either submit@scirp.org or Online Submission Portal.
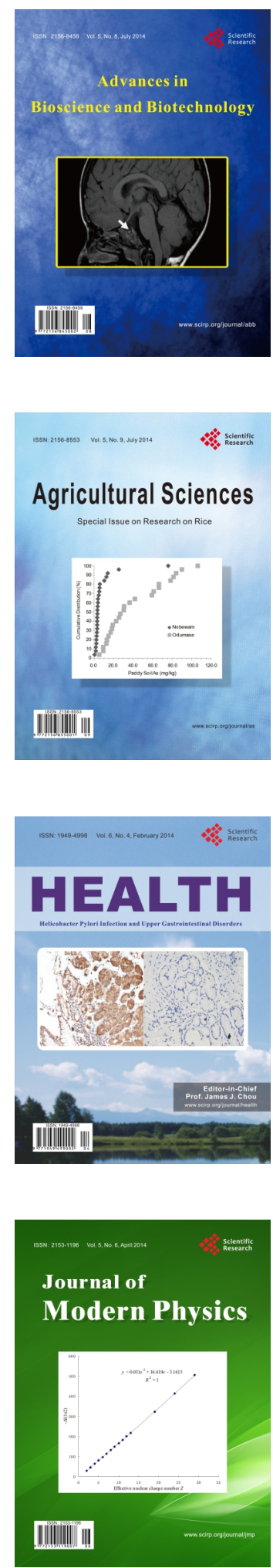
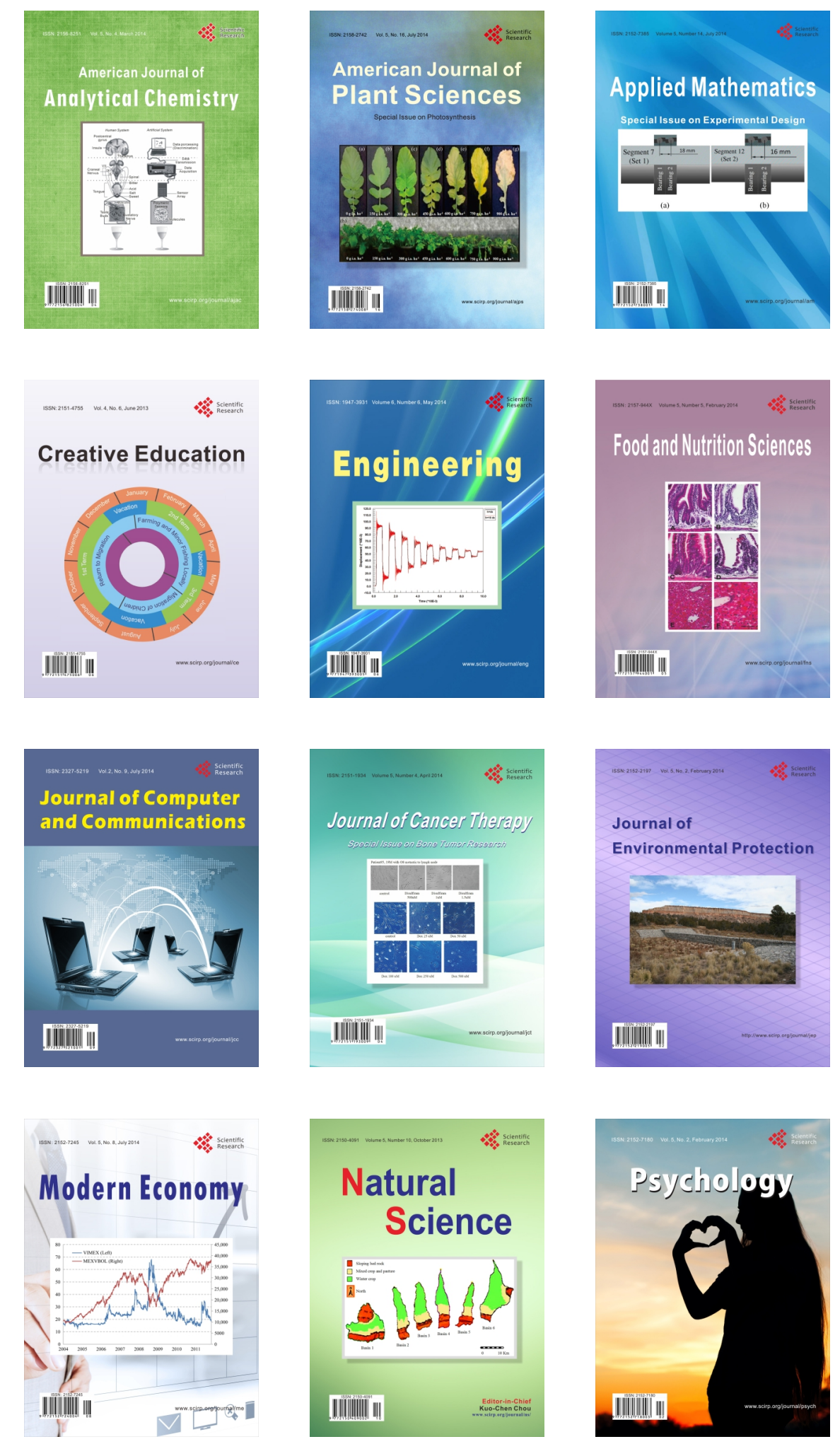